\title{
Pembuatan Website Pariwisata Unggulan Daerah Di Kota Jepara
}

\author{
Syarif Hidayatullah, Herry S. Mangiri, S.T., M.Eng, R. Irlanto Sudomo, M.Pd \\ Universitas Ivet Semarang \\ Email: syarif6696@gmail.com
}

\begin{abstract}
ABSTRAK
Tujuan Penelitian ini adalah 1). Membuat website kepariwisataan daerah untuk mengenalkan objek wisata daerah Kota Jepara. 2). Website yang dibuat dapat membantu wisatawan menemukan lokasi wisata tujuan dengan fitur maps yang disediakan pada website.

3). Website yang dibuat dapat membantu wisatawan menghubungi pengelola dengan fitur whatsapp yang secara otomatis terhubung ke pengelola tanpa harus menyimpan nomor telepon pengelola.

Penelitian Research and Revelopment ini menggunakan metode waterfall yang terdiri dari tahap studi penelitian, analisis, desain, pengembangan, implementasi, penilaian. Subjek penelitian ini adalah masyarakat Jepara, dan pegawai Dinas Pariwisata dan Kebudayaan (DISPARBUD) Kota Jepara Bidang Teknologi Informasi. Data diperoleh dengan wawancara, observasi dan dokumentasi. Analisis data digunakan analisis deskriptif kualitatif.

Hasil penelitian ini berupa website yang telah dibuat dan diujicobakan dengan melibatkan masyarakat umum dan Dinas Pariwisata kabupaten Jepara. Implementasi ujicoba dilakukan dengan mengakses website pariwisata secara olnile melalui internet. Hasil ujicoba website yang diakses melalui internet secara online dapat berjalan dengan baik sehingga website tersebut dapat memberikan informasi bagi masyarakat khususnya yang diluar Jepara untuk mencari referensi objek wisata yang ingin dikunjungi.
\end{abstract}

Kata Kunci: Website Pariwisata, Kota Jepara.

\section{ABSTRACT}

The purpose of this study is 1). Creating a regional tourism website to introduce Jepara City tourism objects. 2). The website created can help tourists find the destination tourist location with the maps feature provided on the website. 3). The website created can help tourists contact the manager with whatsapp feature that is automatically connected to the manager without having to save the manager's telephone number.

Research and Revelopment Research uses the waterfall method which consists of the stages of research studies, analysis, design, development, implementation, assessment. The subjects of this research are the people of Jepara, and employees of the Department of Tourism and Culture (DISPARBUD) of Jepara City in the field of Information Technology. Data obtained by interview, observation and documentation. Data analysis used descriptive qualitative analysis.

The results of this study in the form of a website that has been created and tested by involving the general public and the Department of Tourism of Jepara Regency. The trial implementation is carried out by accessing the tourism website olnile via the internet. The results of testing a website that is accessed via the internet online can run well so that the website can provide information for the public, especially those outside Jepara, to find references to attractions they want to visit.

Keywords: Tourism Website, Jepara City. 


\section{PENDAHULUAN}

Perkembangan pariwisata di Indonesia dari tahun ke tahun sekarang ini semakin pesat. Perkembangan sektor pariwisata sangat menjanjikan dan memberikan manfaat kepada banyak pihak baik untuk pemerintah, masyarakat maupun swasta. Hal ini dikarenakan pariwisata merupakan sektor yang dianggap menguntungkan untuk dikembangkan sebagai salah satu aset yang digunakan sebagai sumber yang menjanjikan bagi pemerintah maupun masyarakat sekitar objek wisata.

Sebagai salah satu upaya untuk memajukan pariwisata daerah adalah perlunya melakukan publikasi yang baik untuk mengangkat nama tempat pariwisata tersebut sehingga destinasi tersebut dapat dilihat dan diketahui oleh pengunjung domestik maupun mancanegara. Sebagai salah satu upaya mengembangkan publikasi tempat wisata yaitu dapat menggunakan media informasi. Salah satu media sebagai sarana informasi dan publikasi yang sangat efektif adalah menggunakan media dalam hal ini adalah website.

$$
\text { Menurut Slamet Riyanto }
$$
(2007:2), Website merupakan tempat penyimpanan data dan penyampaian informasi berdasarkan topik tertentu yang dapat diakses melalui sebuah browser. Dengan menggunakan media website dalam publikasi, semua belahan dunia bisa dijangkau dan potensi tempat pariwisata daerah dapat diketahui oleh siapa saja, bahkan di mancanegara dengan biaya yang murah.

Kota Jepara merupakan sebuah Kabupaten di Jawa Tengah, Kabupaten ini memiliki sejuta pesona dan panorama alam yang menakjubkan dan masih banyak yang tersembunyi, sehingga masih banyak orang yang belum mengetahui akan keindahan destinasi pariwisata yang ada di Jepara. Salah satu penyebab ketidaktahuan masyarakat mengenai tempat wisata yang ada disana adalah lokasi, dimana rute jalan ke lokasi tempat wisata tersebut juga menjadi kendala karena belum adanya fasilitas petunjuk arah menuju lokasi wisata yang tepat di beberapa tempat wisata yang menjadikan wisatawan bingung mencari rute perjalanan ke lokasi wisata. Jepara merupakan kota yang memiliki potensi pariwisata yang cukup lengkap, mulai dari pantai, pulau, bukit atau pegunungan, gardu pandang, hutan pariwisata, religi, peninggalan sejarah, air terjun, waduk, spot foto, waterboom, dan masih banyak lagi.

Dengan banyaknya tempat wisata yang dimiliki tentu membutuhkan media publikasi yang tepat serta didukung dengan rute jalan ke lokasi tujuan untuk mempermudah wisatawan menjangkau lokasi sehingga meningkatkan kunjungan pariwisata. Dengan banyaknya destinasi wisata yang ada, maka perlu publikasi yang baik untuk mengangkat popularitas objek wisata setempat agar dikenal oleh masyarakat luas.

Dengan semakin pesatnya teknologi era sekarang, semakin banyaknya pengguna ponsel smartphone dan komputer dapat dimanfaatkan sebagai media promosi dan informasi dengan dibuatnya website pariwisata milik daerah supaya tempat wisata tersebut dapat diakses dan mudah dicari dengan cara membuatkan halaman website yang menjadi pusat informasi dari semua tempat wisata unggulan yang ada, sehingga semua informasi termuat di satu website tersebut dan didukung dengan fasilitas petunjuk arah untuk menuju ke lokasi. Hal itu akan memudahkan kedua belah pihak baik pemerintah daerah dalam publikasi informasi objek wisata unggulan yang ditawarkan maupun dari pihak wisatawan domestik dan mancanegara untuk mencari destinasi wisata yang diinginkan dan yang ingin dikunjungi.

Berdasarkan uraian latar belakang diatas, maka timbul rumusan masalah, antara lain : Apakah dengan penggunaan media publikasi berbasis website pariwisata daerah mampu mempermudah wisatawan domestik maupun mancanegara untuk 
mengenal dan mengetahui informasi tentang objek wisata yang ada di Kota Jepara?

Adapun tujuan yang ingin dicapai dalam penelitian ini adalah sebagai berikut : (1) Membuat website kepariwisataan daerah untuk mengenalkan objek wisata daerah Kota Jepara. (2) Website yang dibuat dapat membantu wisatawan menemukan lokasi wisata tujuan dengan fitur maps yang disediakan pada website. (3) Website yang dibuat dapat membantu wisatawan menghubungi pengelola dengan fitur whatsapp yang secara otomatis terhubung ke pengelola tanpa harus menyimpan nomor telepon pengelola.

\section{METODE PENELITIAN}

\section{Metodelogi Penelitian}

Metode Perancangan yang akan peneliti gunakan adalah metode Waterfall, Adapun tahapan-tahapan metode Waterfall adalah sebagai berikut:

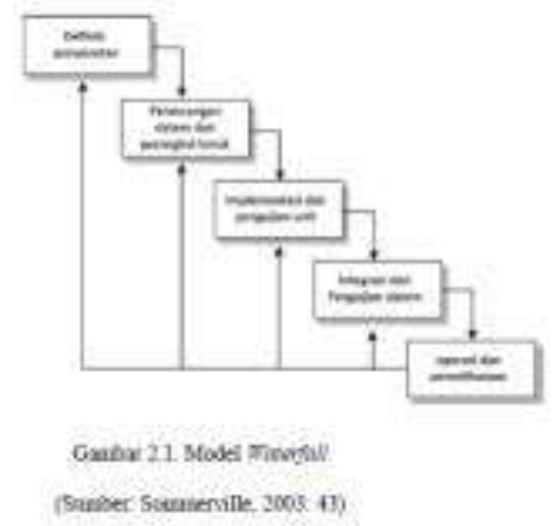

Tahap-tahap utama dari model Waterfall menurut Sommerville (2003: 43) antara lain: (1) Analisis dan definisi persyaratan. Adapun persyaratan dalam membangun website ini perlu dirancang dan didefinisikan dalam struktur sebagai berikut. Terdapat dua fasilitas pada website berdasarkan sudut pandang penggunanya, yaitu fasilitas umum dan khusus. Fasilitas umum ditujukan untuk user, sedangkan fasilitas khusus ditujukan untuk administrator.

Tabel 3.1. Hak akses berdasarkan penggunaannya

\begin{tabular}{|c|c|c|}
\hline No & Pengguna & Hak Akses \\
\hline \multirow{6}{*}{1} & \multirow{6}{*}{ Administrator } & $\begin{array}{l}\text { Mengelola data } \\
\text { website }\end{array}$ \\
\hline & & Mengakses website \\
\hline & & $\begin{array}{l}\text { Memasukkan } \\
\text { konten tempat } \\
\text { pariwisata }\end{array}$ \\
\hline & & $\begin{array}{l}\text { Memperbarui } \\
\text { konten pariwisata }\end{array}$ \\
\hline & & $\begin{array}{l}\text { Memperbarui } \\
\text { Informasi }\end{array}$ \\
\hline & & $\begin{array}{l}\text { Memelihara sistem } \\
\text { website }\end{array}$ \\
\hline \multirow[b]{3}{*}{2} & \multirow[b]{3}{*}{ User } & Mengakses website \\
\hline & & $\begin{array}{l}\text { Mencari informasi } \\
\text { pariwisata }\end{array}$ \\
\hline & & 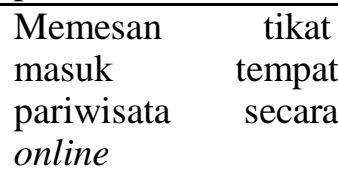 \\
\hline
\end{tabular}

(2) Perancangan sistem dan perangkat lunak. Setelah melakukan analisis, kegiatan selanjutnya yaitu menentukan arsitektur sistem secara keseluruhan, berupa perancangan (a) Data Flow Diagram (DFD), Data Flow Diagram (DFD) adalah suatu diagram yang dirancang menggunakan notasi-notasi untuk menggambarkan arus dari sistem, yang penggunaannya sangat membantu untuk memahami sistem secara logika, tersruktur dan jelas serta menjelaskan sistem yang sedang berjalan logis.

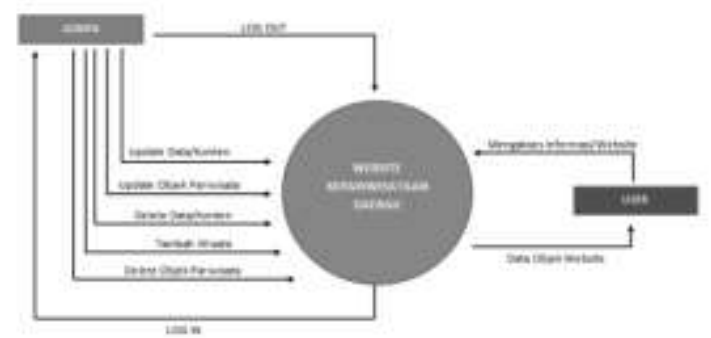

Gambar 3.1. Data Flow Diagram pada website 
(b) Algoritma, merupakan urutan atau langkah-langkah untuk menjelaskan jalannya suatu sistem yang akan dirancang secara berurutan. Dalam pembuatan website pariwisata ini dibutlah algoritma untuk menjelaskan tahapan atau alur system yang akan diterapkan.

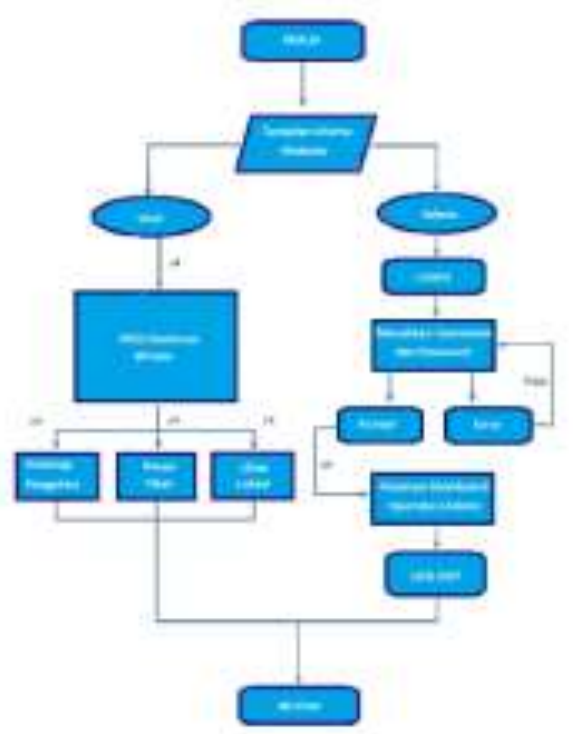

Gambar 3.2. Struktur algoritma website

(c) Perancangan struktur user, pada bagian ini menjelaskan tentang struktur menu apa saja yang ada atau yang dapat digunakan oleh user, adapun struktur tersebut adalah sebagai berikut:

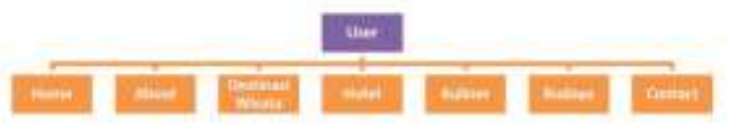

Gambar 3.2. Struktur user website

(d) Perancangan struktur admin, Pada bagian ini menjelaskan tentang struktur menu yang ada atau yang dapat digunakan oleh administrator, adapun struktur tersebut adalah sebagai berikut:

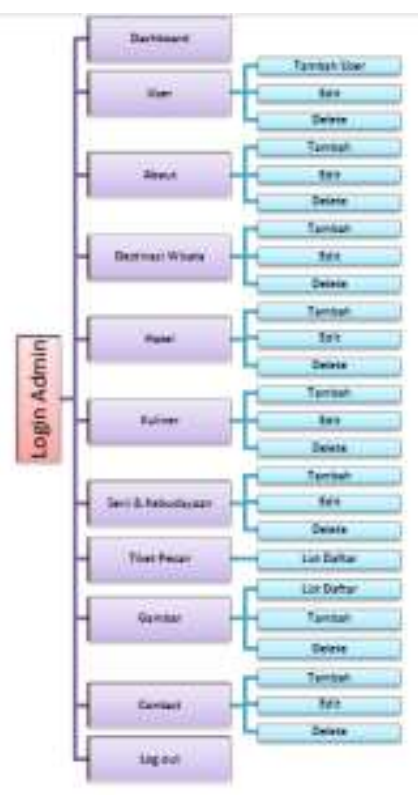

Gambar 3.3. Struktur admin pada website

(e) User interface (Perancangan antar muka pengguna). Perancangan antarmuka pengguna dilakukan dengan membuat desain antarmuka sebagai gambaran dalam tahapan implementasi perangkat lunak. Berikut adalah desain user interface dari sistem yang akan dibuat.

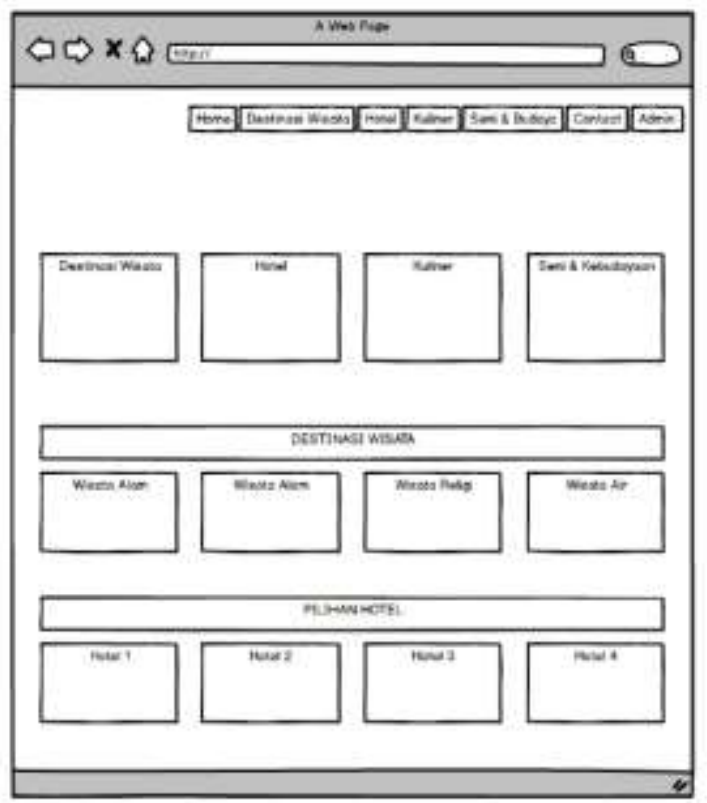

Gambar 3.5. Desain Home Page

(3) Implementasi dan pengujian unit. Peneliti akan membuat coding yang mambuat desain program dapat dikenali komputer. Adapun 
coding atau bahasa pemograman yang peneliti gunakan adalah bahasa PHP, CSS, dan javascript. Setelah tahapan coding program yang dibangun akan dilakukan pengujian secara langsung baik secara unit. (4) Integrasi dan pengujian sistem. Tahap selanjutnya adalah melakukan implementasi atau merealisasikan perancangan desain menjadi sistem seutuhnya. Dalam merealisasikan, peneliti mulai membuat database, membuat website menggunakan bahasa pemrograman, memasukan data yang dibutuhkan seperti data gambar objek wisata serta alamat serta mengupload file website pariwisata ke dalam database online sehingga nantinya website tersebut dapat diakses melalui internet secara online. Sedangkan tahap pengujian dilakukan dengan mengakses website melalui browser yang ada di komputer maupun melalui smartphone. Sehingga nantinya website tersebut dapat berjalan dan diakses sebagaimana yang diharapkan. (5) Operasi dan pemeliharaan. Setelah sistem melalui tahap pengujian, maka sistem tersebut layak untuk digunakan. Agar sistem mampu berjalan dengnan baik kedepannya, maka perlu dilakukan pemeliharaan terhadap suatu sistem. Sehingga peneliti perlu memberikan petunjuk penggunaan dan perawatan yang harus dilakukan oleh admin untuk melakukan pemeliharaan terhadap sistem informasi website pariwisata tersebut.

\section{Sumber Data Atau Subjek Penelitian}

Sumber data dalam penelitian ini terdiri dari masyarakat umum untuk pengujian website pariwisata. Subjek penelitian untuk pengujian diambil secara random sampling 3 orang, dimana 2 orang sebagai pengguna website dan 1 orang sebagai pengelola website.

\section{Metode Pengumpulan Data}

Dalam melakukan penelitian ini menggunakan beberapa metode pengumpulan data, antara lain: (1) Wawancara. Dalam melakukan analisis kebutuhan, perlu dilakukan wawancara secara terstruktur kepada petugas Dinas Pariwisata dan Kebudayaan Kabupaten Jepara. Dengan adanya wawancara, permasalahan yang ada dapat diidentifikasi, sehingga dapat menganalisis kebutuhan dari pengguna. Serta dengan wawancara ini, peneliti dapat mengetahui respons informan dalam memberikan tanggapan mengenai website tersebut. (2) Observasi. Pada tahap observasi ini peneliti melakukan observasi lapangan ke beberapa tempat wisata untuk mengambil data berupa gambar spot wisata, alamat dan pengelola wisata yang ada di masing-masing objek wisata. Kuesioner merupakan cara mengumpulkan data secara tidak langsung. (3) Kuesioner. Kuisioner berupa pertanyaan yang diberikan kepada informan. Hal ini dimaksudkan untuk mengetahui respon informan tentang hasil website yang telah dibuat. Kuisioner yang diberikan ini dapat sebagai bukti penguat atas respon yang diberikan oleh informan dalam menilai website pariwisata unggulan di kota jepara tersebut.

Untuk mendapatkan hasil yang baik dari produk media website yang telah dibuat, penguji melakukan penilaian dengan cara mengambil hasil tanggapan melalui kuisioner yang diberikan kepada Dinas Pariwisata setempat dengan kriteria penilaian yang sudah dibuat.

\section{Teknik Analisis Data}

Teknik analisis data untuk kelayakan media pembelajaran menggunakan analisis deskriptif. Data yang diperoleh adalah data dari kuisioner kemudian dikonversikan menjadi nilai dengan skala Likert level 5. Data yang sudah dikonversi kemudian dianalisis dan dihitung rata-rata jawaban berdasarkan penilaian setiap jawaban dari responden. Nilai rata-rata jawaban dihitung berdasarkan jumlah nilai jawaban seluruh responden dibagi jumlah responden kali jumlah butir instrumen (Widoyoko, 2014: 111).

Berdasarkan jarak interval klasifikasi nilai, maka dapat disusun klasifikasi kriteria penilaian sebagai berikut: 
Tabel 3.4. Klasifikasi Kriteria Penilaian

\begin{tabular}{|c|c|}
\hline Rerata jawaban & Klasifikasi Penilaian \\
\hline $81 \%-100 \%$ & Sangat Baik \\
\hline $61 \%-80 \%$ & Baik \\
\hline $41 \%-60 \%$ & Cukup \\
\hline $21 \%-40 \%$ & Sulit \\
\hline $0 \%-20 \%$ & Sangat Sulit \\
\hline
\end{tabular}

Pada pengujian ini, analisis data dilakukan cara menghitung rata-rata jawaban berdasarkan skoring setiap jawaban dari kuisioner yang diisi responden. Kriteria penilaian untuk instrumen ini menggunakan skala Likert dengan memberikan lima pilihan jawaban sebagai berikut (Riduwan, 2013:13):

Tabel 3.5. Interval Skala Likert

\begin{tabular}{|c|c|}
\hline Keterangan & Nilai \\
\hline Sangat Baik & 5 \\
\hline Baik & 4 \\
\hline Cukup & 3 \\
\hline Sulit & 2 \\
\hline Sangat Sulit & 1 \\
\hline
\end{tabular}

Hasil dari jawaban responden kemudian dapat dihitung skor maksimal sebagai berikut:

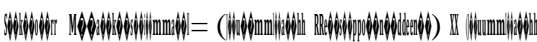

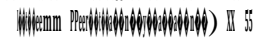

Setelah skor maksimal ditemukan kemudian menjadi acuan untuk menentukan persentase skor total dengan rumus berikut:

$$
\text { Presentase skor total }=\frac{\text { skor total }}{\text { skor maksimal }} \times 100 \%
$$

Setelah didapatkan hasilnya, dibandingkan dengan tabel kriteria interprestasi skor (Riduwan, 2013:15), bisa dilihat pada tabel berikut:
Tabel 3.6. Pedoman Interprestasi Skor Setelah Dikonversi

\begin{tabular}{|c|c|}
\hline Rerata jawaban & Klasifikasi Penilaian \\
\hline $81 \%-100 \%$ & Sangat Baik \\
\hline $61 \%-80 \%$ & Baik \\
\hline $41 \%-60 \%$ & Cukup \\
\hline $21 \%-40 \%$ & Sulit \\
\hline $0 \%-20 \%$ & Sangat Sulit \\
\hline
\end{tabular}

\section{HASIL DAN PEMBAHASAN Hasil Penelitian}

Hasil penelitian ini berupa website yang memuat informasi tentangg pariwisata unggulan daerah di Kota Jepara. Website ini dapat digunakan sebagai media informasi serta media publikasi untuk mengenalkan potensipotensi pariwisata yang ada di Jepara. Pada website ini memiliki dua hak akses dalam penggunaannya yaitu administrator dan user.

Administrator dapat mengelola website pariwisata tersebut karena administrator memiliki hak penuh untuk mengelolah semua data maupun informasi yang akan ditampilkan di halaman website, sedangkan user hanya dapat memilih pariwisata tujuan, melihat lokasi pariwisata tujuan, dan menghubungi pengelola.

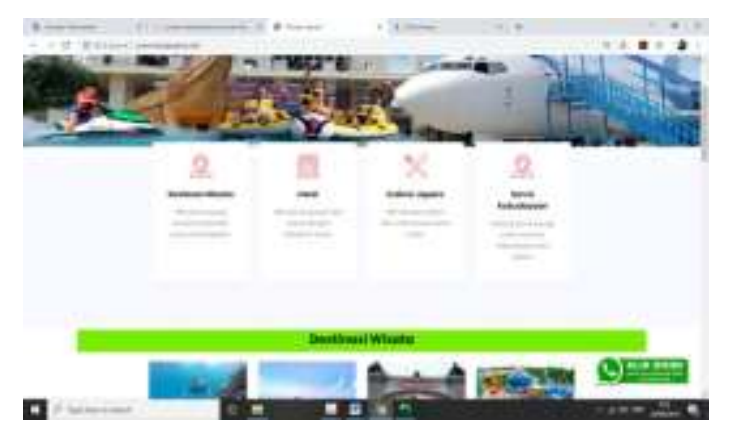

Gambar 4.18. Tampilan Homepage Website Pariwisata

Sedangkan untuk administrator, apabila iningin masuk ke halaman dashboard untuk mengelola website, maka perlu login terlebih dahulu , baru kemudian administrator dapat mengola website melalui dashboard. 


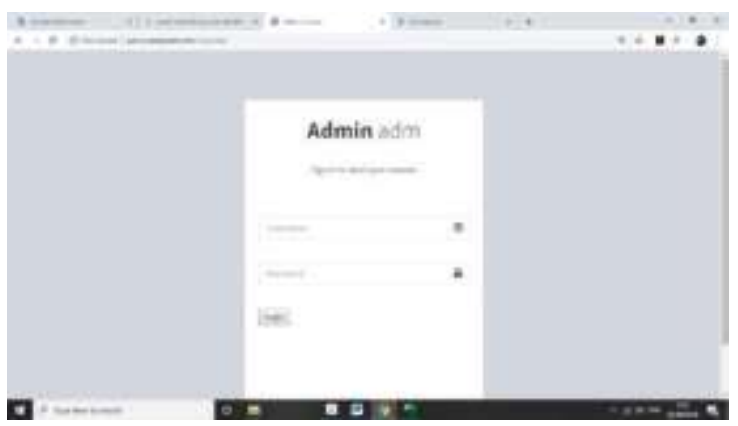

Gambar 4.31. Tampilan Halaman Login Admin

Setelah admin memasukkan username dan password dengan benar, maka akan masuk dan muncul halaman dashboard administrator.

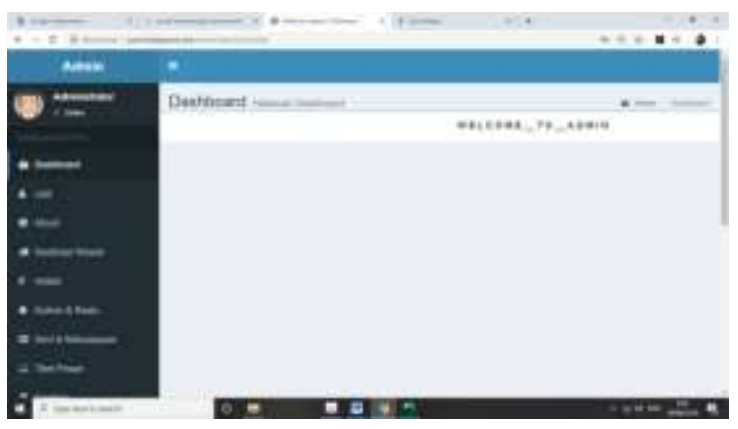

Gambar 4.33. Tampilan Jika Sukses Login Admin

Ketika website di akses melalui smartphone oleh user, maka tampilannya akan terlihat sebagai berikut:

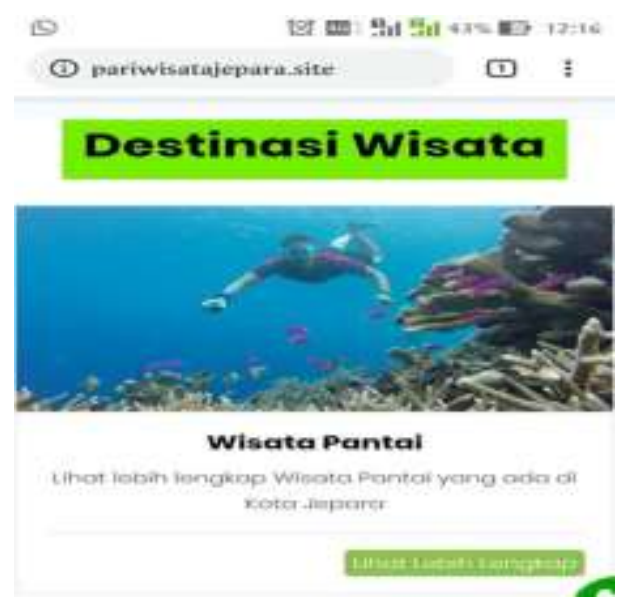

Gambar. 4.88. Website berhasil diakses secara online melalui smartphone
PEMBAHASAN

\section{Deskripsi Hasil Penelitian}

Setelah melaksanakan penelitian maka didapatkan hasil data penelitian yang dibutuhkan untuk membuat website pariwisata. Website pariwisata yang dibuat menggunakan bahasa pemrograman PHP, CSS, HTML sebagai fondasi pembuatan website. Hasil dari pemrograman menggunakan bahasa HTML, CSS dan PHP tersebut menghasilkan beberapa hal diantaranya: (a) Menghasilkan website yang responsif dengan tampilan layout template yang bagus. (b) Website yang dibuat sukses diunggah ke database internet, sehingga website yang telah dibuat dapat diakses secara online melalui browser seperti Mozilla Firefox, Google Chrome, Opera, Edge dan lainya. (c) Website yang dibuat merupakan website satu-satunya yang memuat tentang beberapa tempat pariwisata unggulan yang ada di Kota Jepara dalam satu website.

\section{Deskripsi Hasil Wawancara Dan Kuisioner Deskripsi Hasil Wawancara}

Untuk mendapatkan hasil yang baik serta informasi yang relefan tentang website pariwisata yang sudah dibuat. Peneliti melakukan wawancara sebagai data penguat hasil penelitian. Peneliti melakukan wawancara kepada salah satu masyarakat dan juga kepada Dinas Pariwisata dan Kebudayaan (DISPARBUD) Kota Jepara. Peneliti memperoleh data responden dari hasil wawancara dengan informen.

Menurut Saudari Ela Umiana yang merupakan wisatawan asal Desa Banjarangung Rt 04 Rw 01 mengatakan "website ini sangat baik, karena banyak memuat berbagai macam destinasi pariwisata yang ada di Jepara dan saya setuju karena dapat memberi wadah informasi kepada masyarakat agar masyarakat mengetahui berapa potensi wisata yang ada di jepara yang dapat dikunjungi. Hampir semua wisata termuat didalam website ini. Selama ini juga dalam melakukan promosi wisata masih menggunakan banner, pemberitaan dari orang ke orang dan media facebook, kalau website seperti ini menurut saya sangat membantu 
sekali, apalagi ada konten tambahan seperti hotel sangat baik karena dapat membantu wisatawan dari luar kota untuk mencari refensi pilihan hotel di website tersebut apabila ingin menginap". Hal yang sama juga disampaikan oleh masyarakat Jepara lainnya bernama Nuriswanto, menyatakan bahwa "Website yang tersebut banyak manfaatnya terutama dibidang wisata karena banyak wisatawisata jepara didalamnya. Ini sangat mempermudah orang lain untuk mencari tujuan wisata di jepara dan cukup membantulah bagi masyarakat". Pernyataan tersebut dikuatkan oleh penyataan dari Bapak Lukman Aditya yang merupakan pegawai dari Dinas Pariwisata dan Kebudayaan (DISPARBUD) Kota Jepara di Bidang Teknologi Informasi atau IT, beliau menyampaikan dalam wawancara tersebut bahwa "website pariwisata seperti ini hanya beberapa, namun belum spesifik. Kalau website pariwisata yang memuat wisata secara global belum ada dan menurut saya sendiri itu sangat bagus untuk seperti itu. Dan dengan adanya website kita dimudahkan untuk menyampaikan informasi ke khalayak umum terutama yang ada diluar kabupaten jepara. Apalagi untuk saat ini, di era 4.0 kami masih menggunakan media facebook, instagram, serta membuat leftet dan duplet".

Dari penjelasan kedua informan diatas, bisa disimpulkan bahwa website pariwisata yang telah dibuat ini sangat membantu sekali khususnya dalam mempromosikan pariwisata daerah terutama di era 4.0 ini, dan juga sangat membantu dalam menyampaikan informasi ke khalayak umum terutama yang ada diluar kabupaten jepara bahwa di Kota Jepara terdapat banyak pariwisata seperti pariwisata pantai, alam, religi bahkan wisata buatan atau wisata air menarik yang patut untuk dikunjungi. Dan memang banyak sekali manfaat yang didapat dari website pariwisata ini, selain sebagai tempat promosi pariwisata juga dapat menjadi portal website pariwisata daerah.

\section{Deskripsi Hasil Kuisioner}

Data tanggapan dari pengguna terhadap media website pariwisata unggulan daerah ini dipaparkan dibawah sebagai berikut:

Skor Maksimal $=($ Jumlah Responden $) \mathbf{X}$ (Jumlah Item Pertanyaan) $\mathbf{5}$

Skor maksimal $=3 \times 20 \times 5$

$$
=300
$$

Setelah skor maksimal ditemukan kemudian menentukan persentase skor total dengan rumus berikut:

Tabel 4.5 Hasil Pengujian Tanggapan Pengguna

\begin{tabular}{|l|c|c|c|}
\hline Jawaban & Jumlah & Skor & $\begin{array}{c}\text { Jumlah X } \\
\text { skor }\end{array}$ \\
\hline SS & 1 & 1 & 1 \\
\hline S & 0 & 2 & 0 \\
\hline C & 3 & 3 & 9 \\
\hline B & 37 & 4 & 148 \\
\hline SB & 19 & 5 & 95 \\
\hline \multicolumn{2}{|r|}{ Skor Total } & $\mathbf{2 4 3}$ \\
\hline
\end{tabular}

Berdasarkan hasil perhitungan yang dilakukan diatas, dapat disimpulkan bahwa website pariwisata unggulan daerah di Kota Jepara ini dilihat prosentase skor yang didapat sebesar $81 \%$ dan dapat dikategorikan "Sangat Baik".

Sehingga website ini dapat dijadikan sebagai sarana untuk mengenalkan dan mempromosikan wisata-wisata yang ada di Kota Jepara. 


\section{PENUTUP}

Berdasarkan proses pembuatan dan pengembangan media serta uji coba terhadap media website pariwisata unggulan koja jepara yang memuat berbagai destinasi dan objek wisata di kota jepara, dapat dipaparkan kesimpulan sebagai berikut:(1) Pembuatan website pariwisata ini menggunakan bahasa pemrograman PHP, CSS dan HTML. Terlebih dahulu peneliti membuat desain website terlebih dahulu serta membuat algoritmanya sebelum melakukan coding atau pengkodean. Setelah desain selesai, dilakukan input data seperti data gambar dan data objek wisata. Setelah semua proses selesai, kemudian dilakukan pengujian untuk mengetahui kelayakan media yang telah dirancang. Pengujian tersebut dilakukan dengan mengonlinekan website tersebut sehingga dapat diakses lewat internet. (2) Kemenarikan media website ini dilihat dari hasil implementasi media dan kemenarikan media yang dilihat dari hasil perolehan penilaian kuisioner yang diberikan kepada masyaraka serta hasil wawancara. (3) Efektivitas media website sebagai media informasi dan promosi pariwisata juga dinilai "Baik" oleh Bapak Lukman Aditya dari Dinas Pariwisata Kota Jepara.

\section{DAFTAR PUSTAKA}

Abbas, W. (2013). Analisa Kepuasan Mahasiswa Terhadap Website Universitas Negeri Yogyakarta (UNY). Prosiding SNST Fakultas Teknik, 1(1).

Ainur R. Mulyanto. (2008). Rekayasa Perangkat Lunak Jilid 1. Direktorat Pembinaan Sekolah Menengah Kejuruan.

Anindita, M., \& GUNANTO, E. Y. A. (2015). Analisis Faktor-Faktor yang Mempengaruhi Tingkat Kunjungan ke Kolam Renang Boja (Doctoral dissertation, Fakultas Ekonomika dan Bisnis).

Arief, M.Rudianto. (2011). Pemrograman Web Dinamis Menggunakan Php dan Myspl. Yogyakarta: ANDI.

Badiyanto, S. M. (2013). Buku Pintar Framework Yii. Yogyakarta: Mediakom.

Deitel, P. J., Harvey, M., Abbey, D., (2012). Android How to Program with an Introduction to Java. Prentice Hall: Pearson Education Limited.

Diana, A., \& Setiawati, L. (2011). Sistem Informasi Akuntansi. Yogyakarta: Andi.

Krismiaji. (2015). Sistem Informasi Akuntansi. Yogyakarta: IPP AMP YKPN.

Kristiyanti, M. (2016). Internet Sebagai Media Pembelajaran Yang Efektif. Majalah Ilmiah INFORMATIKA, 1(1).

Mason, Robert, D, (2000). Teknik Statistika Untuk Bisnis dan Ekonomi, Edisi Kesembilan, Erlangga, Jakarta.

Murad, D. F., \& Kusniawati, N. (2013). Aplikasi Intelligence Website untuk Penunjang Laporan PAUD pada Himpaudi Kota Tangerang. CCIT Journal, 7(1), 44-58.

Poerwanto, (2001). Geografi Pariwisata Dalam Diklat Kuliah, Departemen Pendidikan dan Kebudayaan RI, Universitas Jember

Rahayu, Nina. (2014). Perancangan Eksekutive Informasi System. Tangerang: AMIK Raharja. 
Rianto, S. (2007). Membangun Website Dengan Adobe Photoshop dan Macromedia Dreamweaver. Jakarta: Datakom Lintas Batas.

Riduwan. (2013). Metode \& Teknik Menyusun Proposal Penelitian. Bandung : Alfabeta.

Romney, M. B., \& Steinbart, P. J. (2015). Sistem Informasi Akuntansi Edisi 13. Jakarta: Penerbit Salemba Empat.

Rulia Puji, H,. \& Purnama, B. E. (2015). Sistem Penjualan Berbasis Web (E-Commerce) Pada Tata Distro Kabupaten Pacitan. Bianglala Informatika, 3(2).

Saputra, Agus, Feni Agustin, CV. ASKA Solusion. (2013). "Menyelesaikan Website 12 Juta Secara Personal". Jakarta : Bumi Aksara.

Shalahuddin, M., \& Rosa, A. S. (2013). Rekayasa perangkat lunak terstruktur dan berorientasi objek. Bandung: Informatika.

Shawn, Cohan. (2012). Web Statis Dan Dinamis. http://www.infobaru.com/2007/12/web statis dan dinamis.html. Diakses Pada tanggal 2 februari 2017.

Sihotang, H. T. (2018). Sistem Informasi Pengagendaan Surat Berbasis Web Pada Pengadilan Tinggi Medan. Journal Of Informatic Pelita Nusantara, 3(1).

Simarmata, J. (2010). Rekayasa web. Penerbit Andi.

Sommerville, Ian. (2003). Software Engineering, Penerbit Erlangga.

Sugiyono Prof. Dr.,. (2010). metode penelitian kuantitatis, kualitatif, dan R\&D, Bandung : CV. Alfa Beta.

Sugiyono, P. D. (2013). Metode Penelitian Manajemen. Bandung: Alfabeta, CV.

Sugiyono. (2016). Metode Penelitian Kuantitatif, Kualitatif, dan R\&D. Bandung: Alfabeta.

Sulhan, Mohammad. (2007). Pengembangan Aplikasi Berbasis Web dengan PHP \& ASP. Yogyakarta: Gava Media.

Sunaryo, Bambang. (2013). Kebijakan Pembangunan Destinasi Pariwisata Konsep dan Aplikasinya di Indonesia. Yogyakarta: Gava Media.

Sutabri, T. (2012). Analisis sistem informasi. Penerbit Andi.

Tanaamah, A. R., \& Wardoyo, R. (2010). Perancangan Dan Implementasi Webgis Pariwisata Kabupaten Sumba Timur. Jurnal Informatika, 9(2), 150158.

Utama, I. G. B. R. (2017). Pemasaran Pariwisata. Penerbit Andi.

Wibowo, L. A. (2008). Usaha Jasa Pariwisata. Universitas Pendidikan Indonesia.

Widoyoko, E.P. (2014). Teknik Penyusunan Instrumen Penelitian. Yogyakarta: Putsaka Pelajar.

Widagdyo, K. G. (2015). Analisis pasar pariwisata halal indonesia. Tauhidinomics, 1(1), 73-80.

Yoety, Oka A. (2002). Perencanaan Strategis Pemasaran Daerah Tujuan Wisata. Jakarta:Pradnya Paramita.

Yurindra. (2017). Software Engineering. Yogyakarta: Deepublish. 